

\section{The Impact of Liquidity Risk Management on the Financial Performance of Saudi Arabian Banks}

\author{
Ishaq Hacini \\ Abir Boulenfad \\ Khadra Dahou
}

\section{Introduction}

In recent years, liquidity risk has become one of the most important contemporary challenges facing the banking system in the world and Arab banking in particular. Liquidity becomes a major risk in banking operations and liquidity management has received great intention from regulators and policy-makers. In the modern theory of financial intermediation, banks exist in the economy for their roles in providing liquidity and transferring risk (Azam, 2017). For the liquidity risk, two explanations can be provided. First, the deposits on the liability side of the balance sheet create the instantaneous liabilities irrespective of the outcome of the usage of funds on the asset side. Thus, if the optimal employment is not made, a discord on the liability and asset side will be observed. Secondly, the flow of short period liabilities, as well as the dues of other banks fund the medium to small period assets. The liquidity issue also emerges for the reason that, the depositors set to get back their deposits, but the bank does not have the necessary cash in hand. In reality, banks discover a variance in the asset and liability side on an orderly basis and have to control that carefully or they would be facing solvency risks (Anjum, 2012).

Liquidity risk management is highly important for not only banks but also for the total system since the consequences of liquidity insufficiency can be extremely felt on both scales from the bank to the full system. Therefore, banks are responsible for sound management of liquidity risk, which focuses on conserving enough level of liquidity, moreover being ready to face a range of pressure situations, probable losses, or weakness of funding sources (Sviatlana \& Lara, 2017).

Proper and efficient management of liquidity improves the financial performance, which occupies a special position at present. The financial performance determines the bank's efficiency and the extent to which it achieves its objectives. Moreover, through it, it reveals the advantages and disadvantages of performance during a specific period and analyzes its causes. These are consolidating the positive aspects and overcoming the negatives. Also, contributing to raising the level of performance in the future and avoiding risks (Abbas \& Mourouj, 2015).

The study focuses on the effect of liquidity risk management on the financial performance of Saudi Arabian banks. In light of the foregoing, the following problem is raised: Does liquidity risk management affect the financial performance of Saudi Arabian banks?

\section{Literature Review}

The concept of liquidity emerges from various economic perspectives. Liquidity can be defined in the sense of how easy to sell a security and how easy to receive financing to trade a security. The first being called market liquidity and the latter being liquidity financing (Godfrey, 2015).

Bank liquidity stands for the bank's capacity to satisfy financial commitments, as they are due. Liquidity in commercial banks implies the capacity of the bank to fund, where appropriate, all its contractual obligations, which can include the lending, investment and withdrawal of deposits and the maturity of liabilities in the normal course of banking operations (Md Reaz, syed M, \& Saurav, 2016). Liquidity risk is the actual or future risk resulting from the failure of an entity to fulfill its liabilities/obligations when they are due without incurring unreasonable losses. This is commonly called the liquidity risk of funding. There is a business dimension of liquidity risk becoming more significant in recent years, where a great dependence on financing institutions exists (Aldo, 2015). Liquidity risk is the one that arises from the inability of a bank to fulfill its obligations when they are due without incurring unacceptable losses. As depositors may call their funds at inappropriate times, triggering the selling of assets by fire has a negative effect on the bank's profitability (Erika \& Raimonda, 2014).

Liquidity management refers to the preparation and control needed to ensure that the company retains adequate liquid assets either as an obligation to satisfy the incidental lenders' demand or as a measure to apply the requirements of the monetary authorities (Olagunju, Adeyanju, \& Olabode, 2011). The key goal of liquidity management is to ensure that the cash inflows of a bank are matched with its cash outflows. If sustained across all banks, this equilibrium promotes the development of a sound and stable banking sector, which is a necessary element in the successful execution of banking intermediation. The objectives of bank liquidity management can be summarized as follows: Meeting all cash outflow obligations constantly on a regular basis (both on- and off-balance sheet), evading the obtaining of funds at market premiums or via the involuntary sale of assets, compliance with stipulated liquidity conditions and statutory reserve requirements (Farai, 2020).

Many theories emerged to discuss the liquidity management. Anticipated Income Theory states that, the bank can control its liquidity through the careful management of loans issued and the ability to receive these loans on time when they are due which helps to minimize the risk of repayment delays at maturity. This theory implies that, the bank will schedule its liquidity based on the borrower's expected income. This policy allows the bank to issue medium and long-term loans in addition to short-term loans, as long as the repayment of those loans is related to the regularity of the borrowers' expected income.

According to this theory, this policy enables the bank to hold high liquidity (Enekwe, Eziedo, \& Agu, 2017). Commercial Loan Theory states that the selfliquidation of the short-term debt and the funding of working capital achieve the bank's liquidity automatically. Creditors successfully repay the borrowed funds after the completion of their business cycles. 
According to this theory, the banks do not lend money to purchase real estate or consumer goods or for investing in stocks and bonds, due to the length of the expected payback period of these investments. This theory is suitable for traders who need to fund their particular trading transactions in short periods (Ali, 2015). The trade-off theory states that, holding cash reserves under ideal capital market assumptions neither generates nor destroys the corporate value. When the need occurs, the bank can always raise funds from capital markets, where there are no transaction costs in raising these funds. Funds may be collected at a fair price, since it is believed that the financial markets are completely informed about the bank's prospects.

According to the tradeoff principle, banks seek to balance between the profit and costs of keeping cash at an acceptable level. Due to liquidity premiums and tax drawbacks, the cost of keeping cash has a low rate of return. The advantages of holding cash are saving transaction costs to collect funds, in which the assets are liquidated to make payments, and the use of liquid assets to finance their operations and investments, where there are no other sources of financing available (Daniel, 2017). Shiftability Theory implies that the liquidity of a bank is retained if the bank can retain assets that could be transferred or sold to cash easily. This point of view argues that the liquidity of a bank will be increased if it has assets to sell which can be shifted on to the central bank, which is the lender of the last resort. This theory also suggests that the shiftability, marketability, or transferability of the assets of a bank is the foundation for maintaining liquidity. The liquidity management theory focuses on the bank balance sheet's liability hand. This theory suggests that supplementary liquidity can be extracted from a bank's liabilities (Moses, Tobias, \& Margaret, 2018).

Liquidity risk management for banks focuses on the ability of the bank to finance its activities and fulfill its obligations on time and at a reasonable cost. It also means the compatibility between financial reserves and employment in various assets in the medium and short term. This requires studying the nature of the bank's deposits and the pattern of the cost of obtaining these deposits, the return realized from the use of these deposits in other investments, and the adequacy of this return to match the cost of deposits on the one hand (Ahlam \& Aicha, 2015).

There are three facets of liquidity risk management: Assessment and management of net funding needs, market access, and contingency planning. A significant part of liquidity risk management is the estimation of potential future events. The analysis of net subsidizing prerequisites involves the construction of a maturity ladder and the calculation of the cumulative net excess or deficit of funds on selected dates.

Banks should periodically estimate the potential money projected in the future. Flows instead of concentrating solely on written agreements with liquidity within which Forward or backward will scroll. Analyzing whether a bank is liquid depends on the conduct of flows under different circumstances. Liquidity risk control can provide several possibilities. The "going-concern" scenario has established a benchmark for balance sheetrelated cash flows during the normal course of business. Liquidity risk management must therefore involve various scenarios (Saleh, 2014).
In general, this scenario is extended to the management of deposits by the bank. The second state of affairs takes into account a bank's liquidity into the crisis, in which a large portion of its liabilities cannot be repaid or substituted, i.e. the contraction of a bank record. This scenario relates to many provisions of current management measures of cash or liquidity. A third scenario refers to a general financial crisis in which liquidity is affected. During this scenario, liquidity management relies on credit quality, with crucial variations in financing access between banks. An implicit presumption would be generated for liquidity management that the central bank will guarantee access to some kind of finance. Central banks are interested in learning this scenario because of the need to build a buffer of total liquidity for the banking sector and to practically unfold the liquidity burden among key banks (Azam, 2017).

The liquidity risk is usually measured by the financial ratios based on banks' financial statements. The cash to Total Assets Ratio is used to measure the liquid assets of the bank. The increase in this ratio indicates that there are untapped cash balances, which reduces the bank's profitability. The decrease in this ratio from its standard rates means that the bank is exposed to many risks, and the bank will enable to face sudden withdrawal (Najla \& Tahani, 2020). Total Cash and Short-Term Investments to Total Assets Ratio indicates a decrease in the bank's liquidity risk, due to the increase in cash balances and investments with banks and the increase in their ratio to the ratio of total assets, which allows the bank to face its various obligations (Lebbaz \& Boukhari, 2020). Loans to Total Deposits (LTD) Ratio is typically a utilized measure for evaluating liquidity and credit risk, which is estimated by separating the banks' total loans or total financing by its total deposits. This ratio shows, in any case, the level of a bank's loans funded through deposits. On the opposite hand, a high LTD ratio may show a lot of things, but from a liquidity standpoint. A high level of this ratio indicates a possibility of no liquidity and failure due to deposits because they are a completely constant source of funding for a bank. That's why a higher loan deposit ratio means supplementary financial pressure by making too many loans. Therefore, a lower mortgage deposit ratio is continually beneficial to the better one (Mustafa, 2014).

Financial performance refers to the act of conducting the financial activity. Financial efficiency, in a wider context, refers to the extent to which financial targets have been achieved. It is used over a given period to calculate the total financial health of the bank (Tahiri, 2018).

Financial performance refers to the extent to which a bank's financial targets are achieved. In monetary terms, financial results would calculate a bank's outcomes to get a competitive edge over the rivals. Banks can set up the best financial and non-financial systems (Harrison, 2015).

The value of banks' financial performance stems from the fact that it seeks to assess the banks' performance by determining the banks' strengths and weaknesses. The performance evaluation helps the managers to make decisions and strategies. The value of financial performance also stems from the process of monitoring the conditions of the bank, evaluating its actions, directing performance in the right direction and leading to sound decision-making. Financial performance 
is also important for the external climate, as a bank with high financial performance is more able to adapt to new environmental challenges and opportunities and can also take advantage of different investment opportunities (Tahir \& Wael, 2007).

The value of financial performance is not limited exclusively to the bank, but also to the investor. Where, the investor can follow up and learn about the operations of the bank, track the economic and financial circumstances surrounding it, and determine the extent of the effect of financial performance instruments in terms of profitability, liquidity, operation, and other aspects. Moreover, the course of reviewing, evaluating and interpreting the financial statements allows the financial performance of the investor to take the appropriate decision according to the banks' conditions (Mahmoud, 2010).

Profitability is the first line of protection for a bank against unforeseen losses. It reinforces its capital position and increases potential profitability through retained earnings investment. Ultimately, an entity that persistently makes a loss will deplete its capital base, placing equity and debt investors at risk in turn. All of the strategies and activities are built by the bank to optimize the benefit of the bank to measure profitability (Zawadi, 2013, p. 136). Profitability is measured using the Return on Assets (ROA), Return on Equity (ROE), Return on Resources (ROR) and Net Interest Margin (NIM).

Return on Assets (ROA) is the revenue earned by the bank related to the assets used in business operation. It is calculated as net income/total assets (or pre-tax profit). It offers details about the success of management in using the company's assets to produce profits (Mustafa, 2014). Return on Equity (ROE) measures the profitability of the equity capital of a bank. Its value is of particular interest to the bank's shareholders. It is roughly equal to the size of net profit to which shareholders are obliged to make their capital investments. This is the risk they are taking by spending their funds to ensure an acceptable amount of profit (Havryliuk, 2017). Return on Resources (ROR) is formulized by [Net Profit After Tax / (Total Deposits + Equity)]. This rate shows the share of each resource unit, whether independent or external, in the net profit achieved. This shows the efficiency of the bank in achieving income from the resources available (Zaher, 2011). Net Interest Margin (NIM) is a measure of the difference between the interest income generated by banks and the amount of interest paid out to their lenders (for example, deposits), relative to the amount of their (interest-earning) assets. The NIM variable is defined as the net interest income divided by total earnings assets (Vincent \& Gemechu, 2013).

The focus of this research is to explore the impact of liquidity risk management on financial performance. Eyob (2019) examined the effect of liquidity risk on the financial performance of Ethiopian commercial banks. Balanced data of nine commercial banks were collected from 2007 to 2016. Eight factors that might affect the financial performance of Ethiopian commercial banks were selected and analyzed. The result of panel data analysis showed that liquidity coverage ratio, net stable funding ratio, loan to deposit ratio and liquidity ratio have negative effects on Ethiopian commercial banks' financial performance.

Saifullah, Rashed, \& Alamgir (2019) studied the relationship between liquidity and financial performance of commercial banks in Bangladesh. The investigation was performed using the panel data method for a sample of 31 commercial banks listed in the Dhaka Stock Market between the years of 2010-2017. According to the research, liquidity did not have an impact on return on asset (ROA) and return on equity (ROE).

Laminfoday (2018) tried to understand the association between liquidity risk management and financial performance of commercial banks in Sierra Leone. The study focused on eight commercial banks and a descriptive study design was adopted. Secondary data were collected covering five years from 2013 to 2017 . The result of this research shows a significant negative nexus between liquidity risk management and financial performance of commercial banks in Sierra Leone. The study also reveals that liquid assets to total assets had the greatest impact on financial performance and had an inverse relationship.

Abbas \& Mourouj (2015) examined the impact of the important banking indicators, such as liquidity risk indicators on financial performance. The study selected a sample of (47) banks in Iraq for a period of ten years from 2005 to 2014. They started from the hypothesis that, the strongly positive relationship among those indicators and the banking financial performance had an important effect in realizing a sound banking financial performance. On the other hand, a strong banking system sustained economic growth and protected the local economy during crises. Finally, researchers reached a set of conclusions, including the high percentage of cash and cash assets compared to other assets at banks. This indicates the accumulation of non-profitable liquid funds in them, which greatly affected the various financial performance ratios they have, and this may reflect the fear of bank administrations from entering into investment fields involving some kind of risk.

\section{Methodology}

Data

This study investigates the impact of liquidity management risk on the financial performance of Saudi Arabian banks for the period of 2002-2019. The data were retrieved from the banks' annual financial reports.

\section{Model Specification}

Return on equity (ROE) was selected as the main proxy for bank financial performance.

ROE reflects how effectively a bank manages the shareholders' equity. It shows how much the bank earns from the shareholders' equity (Berrani \& Hacini, 2021). ROE is an important measure of banking returns because it indicates whether a bank can do well relying on its resources (Farhi \& Hacini, 2021). ROE is the net income divided by average equity (Noraini, 2012).

Cash to total deposit ratio (CTD) and loan to deposit ratio (LTD) measure the liquidity management risk. CTD shows how much can a bank lend according to the deposits that were mobilized. It also measures the banking main activity (Suman \& Raj, 2016). LTD is commonly used as a statistic for assessing the bank's liquidity. It is calculated by dividing the bank's total loans by the total deposits. If the ratio is too high, it means that banks might not have enough liquidity to cover any unforeseen fund requirements. If the ratio is 
too low, the bank profitability may be deteriorated (Saleh, 2014).

Equity to Assets Ratio (ETA) is a financial indicator that is used to measure the owner's motivation to continue for holding the bank. This ratio examines the ability of bank's equity to finance the bank assets (Fahrul $\&$ Buyung, 2018). The functional relationship among ROE, liquidity risk and the other factors can be expressed as follows: it) + eit

$$
\text { ROE it }=\beta 0 i t+\beta 1(\text { CTD it })+\beta 2(\text { LTD it })+\beta 3(\text { ETA }
$$

Table 1 shows that LTD has the highest mean value (0.765) and CTD has the lowest mean value (0.126). Average CTD and LTD indicate that Saudi Arabian banks are lowly liquidated to pay off their creditors and their loans are more than their deposits. The standard deviation indicates that the values were widely dispersed from their mean values. This means that as the mean value increases, the value of standard deviation will also increase and vice versa. The low standard deviation of ETA implies that it does not deviate more than its mean.

Table 1: Variables' Descriptive Statistics

\begin{tabular}{|c|c|c|c|c|c|}
\hline Variable & Mean & Std. Dev & Min & Max & Observations \\
\hline ROE & 0.1662 & 0.0674 & 0.0170 & 0.3405 & $\mathrm{~N}=123$ \\
\hline CTD & 0.1266 & 0.0559 & 0.0053 & 0.3013 & $\mathrm{~N}=123$ \\
\hline LTD & 0.7650 & 0.1028 & 0.5315 & 0.9464 & $\mathrm{~N}=123$ \\
\hline ETA & 0.1348 & 0.0277 & 0.0756 & 0.2115 & $\mathrm{~N}=123$ \\
\hline
\end{tabular}

Source: Stata Software Output

\section{Results and Discussion}

\section{Stationarity Test}

The stationarity is tested using the Pesaran test. The test is built on two hypotheses. H0 hypothesis states that the time series contains a unit root indicating that they are not stable over time (no stationary) and the alternative hypothesis $\mathrm{H} 1$ states that the time series does not contain a unit root meaning that it is stable (stationary).
$\mathbf{H}_{\mathbf{0}}$ : There is a unit root (no stationary)
$\mathbf{H}_{1}$ : There is no unit root (stationary)

Table 2: Pesaran s CADF Test

\begin{tabular}{|c|c|c|}
\hline Variables & Z(t-bar) & P- value \\
\hline ROE (level) & -3.062 & $0.001^{*}$ \\
\hline CTD (level) & -1.801 & $0.078 * *$ \\
\hline LTD (level) & -1.422 & $0.078^{* *}$ \\
\hline ETA (level) & 0.337 & 0.632 \\
\hline ETA (2 difference) & -3.736 & $0.000^{*}$ \\
\hline \multicolumn{2}{|c|}{$*=$ significant at 5\%, ${ }^{* *}=$ significant at $10 \%}$.
\end{tabular}

Source: Stata Software Output

The results in Table 2 indicate that ROE has pvalues less than $5 \%$, the null hypothesis is rejected and ROE is stationary at the level. The results of the test for CTD and LTD indicate that the p-value is less than 0.1 (significant at 10\%). Therefore, the null hypothesis is rejected and the two variables are stationary at the level. Equity to assets ratio (ETA) variable indicates that the pvalue is more than $5 \%$ and $10 \%$, which means that the null hypothesis can not be rejected. This means that the variable contains a unit root and it is not stationary. The results also show that ETA's p-value is less than 5\%. Thus, the null hypothesis is rejected and ETA at the second difference does not contain a unit root and it is stationary.

\section{Model Estimation}

The study's model is estimated according to three methods: Ordinary Least Squire (OLS), Fixed Effect and Random Effect.

Table 3: OLS Results

\begin{tabular}{|c|c|c|c|c|}
\hline Variable & Coef & Std & T & P \\
\hline CTD & -0.2544 & 0.1216 & -2.09 & $0.039^{*}$ \\
\hline LTD & -0.2328 & 0.0766 & -3.04 & $0.003^{*}$ \\
\hline ETA & -0.1947 & 0.2853 & -0.68 & 0.497 \\
\hline Cons & 0.3781 & 0.0657 & 5.75 & $0.000^{*}$ \\
\hline Num Obs & \multicolumn{5}{|c|}{0.107} \\
\hline $\mathrm{R}^{2}$ & 0.0757 \\
\hline Adj R & \multicolumn{5}{|c|}{0.0111} \\
\hline Prob F & * significant at 5\%, **=significant at $10 \%$. \\
\hline
\end{tabular}

Source: Stata Software Output

Table 3 shows that OLS model fits well the data where F (P- value) equals 0.0111. The variables' coefficients analysis indicates that CTD $(\mathrm{p}$-value $=0.039)$ and LTD ( $\mathrm{p}$-value $=0.003$ ) have significant negative effects on ROE, while ETR ( $p$-value $=0.497$ ) have no significant effect on ROE. 
Table 4: Fixed-Effects results

\begin{tabular}{|c|c|c|c|c|}
\hline Variable & Coef & Std & T & P \\
\hline CTD & -0.3871 & 0.1404 & -2.76 & $0.007^{*}$ \\
\hline LTD & -0.4085 & 0.1041 & -3.92 & $0.000^{*}$ \\
\hline ETA & -0.2378 & 0.2705 & -0.88 & 0.381 \\
\hline Cons & 0.5336 & 0.0917 & 5.81 & $0.000^{*}$ \\
\hline Num Obs & \multicolumn{4}{|c|}{07} \\
\hline Num of Groups & \multicolumn{4}{|c|}{07 i $0: \mathrm{F}(6,97)=3.08$} \\
\hline F test & \multicolumn{3}{|c|}{0.0083} \\
\hline Prob>F & \multicolumn{3}{|c|}{} \\
\hline
\end{tabular}

$*=$ significant at $5 \%, * *=$ significant at $10 \%$

Source: Stata Software Output

To test the appropriateness of the fixed effect model, we check the heterogeneity between the banks (i) based on the following hypothesis:

$\mathbf{H}_{0}$ : $\operatorname{sigma}(\mathrm{i})^{\wedge} 2=\operatorname{sigma}^{\wedge} 2$ for all $\mathrm{i}$

$\mathbf{H}_{1}$ : $\operatorname{sigma}(i)^{\wedge} 2 \neq \operatorname{sigma}^{\wedge} 2$ for all $i$

Table 4 shows that $F(6,97)=3.08$, Prob $>F=$ 0.0083 , so the $\mathrm{H} 0$ is rejected and the fixed effect model is appropriate because there is heterogeneity between the banks. CTD and LTD have negative significant effects on the ROE, while ETA has no significant effect on the ROE.

Table 5: Random-Effects GLS results

\begin{tabular}{|c|c|c|c|c|}
\hline Variable & Coef & \multicolumn{1}{|c|}{ Std } & T & P \\
\hline CTD & -0.2936 & 0.1275 & -2.30 & 0.021 \\
\hline LTD & -0.2954 & 0.08671 & -3.41 & 0.001 \\
\hline ETA & -0.2124 & 0.2737 & -0.78 & 0.438 \\
\hline Cons & 0.4315 & 0.07545 & 5.72 & 0.000 \\
\hline Num Obs & \multicolumn{5}{|c|}{107} \\
\hline Wald chi2(3) & \multicolumn{5}{|c|}{0.0035} \\
\hline Prob>chi2 & \multicolumn{5}{|c}{} \\
\hline
\end{tabular}

$*=$ significant at $5 \%, * *=$ significant at $10 \%$

Source: Stata Software Output

Table 5 indicates that $\operatorname{Prob}(\mathrm{Chi} 2)$ of the randomeffects model $(0.0035)$ is less than $5 \%$, which indicates that the model is appropriate. To test the appropriateness of the random-effects model, we use Breusch and Pagan Lagrangian multiplier (LM) test. LM test helps to decide between a random-effects regression and an OLS regression is based on the following hypotheses:

\section{Table 6: Breusch Test}

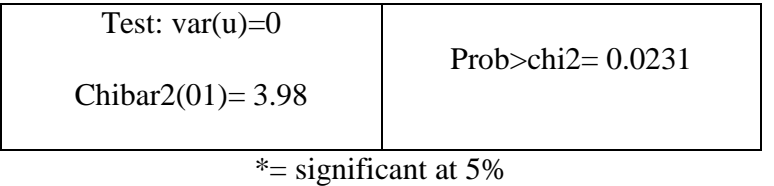

Source: Stata Software Output

Table 6 shows that the Prob (Chi2) of the Breusch test is 0.0231 , which is less than $5 \%$. This indicates that the random-effects model is appropriate for the data. The regression results for the random effects model reveal that CTD has a significant negative effect on ROE, which means there is an inverse relationship between the two variables $=-0.2936706(\mathrm{p}$-value $=0.021)$.

There is a significant negative effect of loan to deposit ratio LTD on ROE, which means there is an inverse relationship between the two variables. This means that the higher the loan-to-deposit ratio, the lower the banks' financial performance. There is a significant negative effect of ETA on ROE, which means there is an inverse relationship between the two variables. This means that the higher the equity to assets ratio, the lower the banks' financial performance. The tests revealed that random and fixed effect models are appropriated compared to OLS. Now we should choose between the random and fixed effects models by applying the Hausman test.

\section{Hausman Test}

For selecting the best model of this data, the Hausman test was used to compare and choose between the results of the random-effects and fixed-effects, by testing the following hypothesis:

$\mathbf{H}_{\mathbf{0}}$ : Random effects model is the appropriate model.

$\mathbf{H}_{1}$ : The fixed effects model is the appropriate model.

Table 7: Hausman Test

\begin{tabular}{|l|l|}
\hline Chi2 $(3)=4.01$ & Prob $>$ chi2 $=0.2605$ \\
\hline
\end{tabular}

Source: Stata Software Output

Table 7 shows that Prob (Chi2) of the test is more than $5 \%(0.260)$. Therefore, we cannot reject the null hypothesis and the appropriate model is the Randomeffects. The random effect model is more appropriate for explaining the effect of liquidity risk on financial performance compared to the fixed effect model.

\section{Random-effects GLS regression (robust)}

To solve the problem of heteroscedasticity, we need to apply robust estimation for the Random effect to obtain heteroscedasticity-robust standard errors (known as Huber/White or sandwich estimators).

$\mathbf{H}_{\mathbf{0}}$ : No difference across units.

$\mathbf{H}_{1}$ : Difference across units 
Table 8: Random-Effects GLS Robust Results

\begin{tabular}{|c|c|c|c|c|}
\hline Variable & Coef & Std & T & P \\
\hline CTD & -0.2936 & 0.1285 & -2.29 & $0.022^{*}$ \\
\hline LTD & -0.2954 & 0.1279 & -2.31 & $0.021^{*}$ \\
\hline ETA & -0.2124 & 0.0835 & -2.54 & $0.011^{*}$ \\
\hline Cons & 0.4315 & 0.1127 & 3.83 & $0.000^{*}$ \\
\hline Num Obs & \multicolumn{5}{|c|}{22.107} \\
\hline Wald chi2(3) & \multicolumn{5}{|c|}{0.0001} \\
\hline Prob>chi2 & \multicolumn{5}{|c|}{ *= significant at 5\% }
\end{tabular}

Source: Stata Software Output

Table 8 shows that Prob (Chi2) of the randomeffects model (0.0001) is less than $5 \%$, which indicates that the model is appropriate. All independent variables of CTD, ITD and ETR have significant negative effects on ROE.

\section{Discussion of the Results}

The ratio of cash to deposits negatively affects the banks' financial performance. CTD increases when the banks hold cash more than deposits. The increase of CTD gives the bank's customers the trust that the bank will be able to provide the customers' deposits when they request them. On the other hand, when CTD increases above a certain level, funds will be idle and the bank will suffer the opportunity costs and the deposit interest, which negatively affects the bank's performance. Therefore, the Saudi banks maybe hold a large percentage of cash (surplus in liquidity) to face the demand of deposits' withdraw. Moreover, this what is (Mishra \& Pradhan, 2019) suggested previously.

The ratio of loan to deposits negatively affects financial performance indicators, because the loan-todeposit ratio contributes to assessing the bank's liquidity and helps investors to determine whether the bank is properly managed its liquidity. If the ratio is too high, this means that the bank does not have sufficient liquidity to cover any financing requirements such as default on loans or an economic downturn, which in turn greatly and negatively affects the bank's performance. (Abbas \& Mourouj, 2015) and (Laminfoday, 2018) found that the increase of this ratio indicates an increase in the bank's need for new financing sources to meet loan requests. Either borrowing from the money market or selling some assets and this matter is followed by higher financing costs, which leads to lower profits and increased indebtedness.

It was found that banks` management should pay more attention to maintain the optimal loans/total deposits ratio and not over lend to avoid any source of liquidity deficit risk (Thair \& Qais, 2020). This is because more lending will expose the banking sector to high default risk which will adversely affect the banking sector's returns and ultimately its EPS. This also means that the higher the loans granted by banks, the more liquidity risk faced by them, as it decreases the operating cash flow per share generated by banks due to an increase in the amount of cash outflow. The ratio of equity to assets negatively affects financial performance. High ETA means that the bank has less risk. At the same time, the bank may suffer from a shortage of funds to finance its operations and investments. Thus, this leads to deteriorate the bank profitability and minimize the investment's returns. If possible, banks should balance between risk level and profit as suggested by previous research (Bassam, 2016).

\section{Conclusion}

Regarding the importance of liquidity management risk and its effect on the financial performance, this study focuses on studying the subject in Saudi Arabia for the period of 2002-2019. The financial performance is measured by the return on equity (ROE) and liquidity risk is measured by the ratio of loans to deposit and cash to deposit ratio. This research presents several findings.

The results found a negative effect of liquidity risk on the financial performance of Saudi Arabian banks. The loan to deposit ratio has a negative effect on the financial performance of Saudi Arabian banks. The negative effect is explained as the banks' need for new financing sources to meet loan requests, by borrowing from the money market or selling some assets. This policy leads banks to bear high financing costs, which results in lower profits and increasing indebtedness.

The results also revealed that the cash to deposit ratio negatively affects the banks' financial performance. This is due to cash increasing above a certain level makes funds idle and the bank will suffer from the opportunity costs and the paid deposits interest, which negatively affects the bank's performance. Based on the results of this study, a set of suggestions can be presented. The necessity of preserving some semi-liquid investments to ensure that there is no exposure to any liquidity risk in the future is evident. The bank should take advantage of the excess liquidity available during granting loans and increase its investment. Saudi Arabian banks must invest the excess liquidity to increase the banks' profitability. Saudi Arabian banks also need to adopt creative policies to manage their liquidity efficiently for avoiding risks.

\section{References}

Abbas, K. A.-D., \& Mourouj, T. H. (2015). The impact of bank liquidity risk management on banking financial performance An applied study in a sample of private banks. Journal of Administration and Economics, Vol. 05, No. 20, 73-100.

Ahlam, B., \& Aicha, T. (2015). Liquidity risk management in conventional and Islamic banks a comparative study to banks in Qatar for the period 2011-2014. Economic insights journal, No. $08,104-120$.

Aldo, S. (2015). Liquidity Management, a funding risk handbook. UK: The Wiley finance series Products. 
Ali, S. A. (2015). The Effect of the Liquidity Management on Profitability in the Jordanian Commercial Banks. International Journal of Business and Management; Vol. 10, No. 1, 6271.

Anjum, I. (2012). Liquidity Risk Management: A Comparative Study between Conventional and Islamic Banks of Pakistan. Global Journal of Management and Business Research, Vol. 12, No. 5, 54-64.

Azam, A. (2017). Measuring Liquidity Risk Management and Impact on Bank Performance in Iran. Journal of Money and Economy Vol. 12, No. $3,295-315$.

Bassam, H. (2016). A study to define the effect of financial structure on the financial performance of Islamic banks listed in Damascus securities exchange. Research submitted for obtaining a Magister degree in Business Administration. Damascus, Syrian Virtual University, Syria.

Berrani, M., \& Hacini, I. (2021). The role of corporate governance in improving the banks Financial Performance empirical evidence from listed banks in the Saudi market, Journal of Economic Integration, Vol. 9, No. 2, 651-667.

Daniel, B. E. (2017). Liquidity Management and Performance of Deposit Money Banks in Nigeria (1986 - 2011): An Investigation. International Journal of Economics, Finance and Management Sciences, Vol. 05, No. 03, 146-161.

Enekwe, C. I., Eziedo, K. N., \& Agu, C. I. (2017). Effect of Liquidity Risk on Financial Performance of Selected Quoted Commercial Banks in Nigeria. Journal of Global Accounting, Vol. 5, No. 1, 21-34.

Erika, B., \& Raimonda, M.-K. (2014). Liquidity risk and its management in Lithuanian Banking System. Mokslas-Lietuvos ateitis/Science-Future of Lithuania, 64-71.

Eyob, K. (2019). The Impact of Liquidity Risk on Financial Performance of Commercial Banks in Ethiopia. A Thesis Submitted for the Requirements for the Degree of Magister of Science in Accounting and Finance. Addis Ababa, School of Graduate Studies, Addis Ababa University, Ethiopia.

Fahrul, P. S., \& Buyung, S. (2018). Effect Of Equity To Assets Ratio (EAR), Size, and Loan To Assets Ratio (LAR) On Bank Performance. IOSR Journal of Economics and Finance, Vol. 9, No. $4,1-6$.

Farai, D. D. (2020). The impact of Liquidity Management on Bank Financial Performance in a subdued economic environment: A case of the Zimbabwean Banking Industry. PM World Journal, Vol. IX, No. I, 01-20.
Farhi, M, \& Hacini, I. (2021). The Impact Of The Ownership Diversification On The Financial Performance An Empirical Study On Financial Companies In Qatar. Psychology and Education, Vol. 58, No. 5, 1553-6939.

Godfrey, M. (2015). Liquidity and Bank Performance. International Business \& Economics Research Journal, Vol. 14, No. 3, 453-462.

Harrison, K. S. (2015). The effect of liquidity management on the financial performance of deposit taking Saccos in Nairobi County. Doctoral dissertation, University of Nairobi.

Havryliuk, O. (2017). Indicators of effective bank performance. Technology audit and production reserves, No. 5/5, 39-43.

Laminfoday, D. (2018, December). The Effect of liquidity risk management on financial performance of commercial banks in Sierra Leone. A research proposal submitted for the award of the degree of Magister of business administration. Nairobi, School of business, University Of Nairobi.

Lebbaz, A., \& Boukhari, A. (2020). Risk assessment banking liquidity in Algerian commercial banks using financial analysis indicators - Case study of the Algerian Peace Bank 2015-2018. Journal of Business Administration and Economic Studies, Vol. 01, No. 06, 223-239.

Mahmoud, m. e. (2010). Financial performance and its impact on the stock returns of joint stock companies. Oman: Al Jamid for publication and distribution house, first edition.

Md Reaz, U., syed M, A. R., \& Saurav, D. (2016). Liquidity Risk and Performance: A Study on the Banking Sector of Bangladesh. Business Review- A Journal of Business Administration Discipline, Vol. 11, No. 182, 35-42.

Mishra, S., \& Pradhan, B. B. (2019). Impact of Liquidity Management on Profitability: An Empirical Analysis in Private Sector Banks of India. Revista ESPACIOS Journal, Vol. 40, No. 30.

Moses, O. G., Tobias, O., \& Margaret, O. (2018). Effect of Liquidity Risk on Financial Performance of Deposit Taking Savings and Credit Societies in Kenya. International Journal of economics, commerce and management, Vol. 06, No. 1, 259-283.

Mustafa, H. M. (2014). Evaluating the Financial Performance of Banks Using Financial RatiosA Case Study of Erbil Bank for Investment and Finance. European Journal of Accounting Auditing and Finance Research, Vol. 2, No. 6, 162-177. 
Najla, I. A., \& Tahani, E. A. (2020). The effect of liquidity on the profitability of commercial banks in the Kingdom of Saudi Arabia Period (2010-2019). Journal of Economic, Administrative and Legal Sciences Vol. 4, No. $12,109-132$.

Noraini, M. A. (2012). Liquidity Risk Management and Financial Performance in Malaysia: Empirical Evidence from Islamic Banks. Aceh International Journal of Social Sciences, Vol. 1, No. 2, 77-84.

Olagunju, A., Adeyanju, O. D., \& Olabode, O. S. (2011). Liquidity Management and Commercial Banks' Profitability in Nigeria. Research Journal of Finance and Accounting, Vol. 2, No. 7/8, 24-39.

Ramadan, N. a. (2013). Accounting and Financial Information Role in Liquidity Risk Management, Applied Study on Commercial Banks Working in Gaza Strip. Magister Thesis in Accounting and Finance. Ghaza, department of commerce, Islamic University, Palestine.

Saifullah, K., Rashed, M., \& Alamgir, H. (2019). The Impact of Liquidity Risk on Banking Performance: Evidence from the Emerging Market. Global Journal of Management and Business Research: C Finance, Vol. 19, No. 4, 46-52.

Saleh, T. A. (2014). Bank Liquidity Risk and Performance: An Empirical Study of the banking system in Jordan. Research Journal of Finance and Accounting, Vol. 5, No. 12, 155164.

Suman, G., \& Raj, K. (2016). Analysis of Cash - Deposit Ratio \& Credit Deposit Ratio of Public Sector Banks in India. International Journal of Research in Management, Science \& Technology, Vol. 4, No. 2, 72-74.

Sviatlana, H., \& Lara, G. (2017). Management Strategies for Bank's Liquidity Risk. International Journal of Economics and Finance; Vol. 9, No. 6, 98110.

Tahir, M. M., Wael, M. S. (2007). Strategic management: An integrated methodological perspective. Oman: Wael Publishing House, first edition.

Tahiri, N. R. (2018). Study on financial performance of the Afghanistan Bank 2015 and 2016. Kabul, Afghanistan: MPRA Paper No. 88477.

Thair, A. K., \& Qais, A. A.-K. (2020). The Effect of Liquidity Risk Management on the Jordanian Financial Sector - The Proxy of Commercial Banks. International Journal of Innovation, Creativity and Change, Vol. 14, No. 1, 240253.
Vincent, O. O., \& Gemechu, B. K. (2013). Determinants of Financial Performance of Commercial Banks in Kenya. International Journal of Economics and Financial Issues, Vol. 3, No. 1, 237-252.

Zaher, S. B. (2011). Assess the Financial Performance of Islamic and Conventional Banks Using Financial Indicators. Magister thesis in Accounting and Finance. Department of Commerce, The Islamic University - Gaza, Gaza-Palestine.

Zawadi, A. (2013). Comparative Analysis of Financial Performance of Commercial Banks in Tanzania. Research Journal of Finance and Accounting, Vol. 4, No. 19, 133-143. 